\title{
Competition in Colon Cancer Screening? What Is the Role of Colonoscopy?
}

\author{
Arthur Hoffman Daniel Teubner Ralf Kiesslich \\ Medizinische Klinik, St. Marienkrankenhaus Frankfurt, Frankfurt/M., Germany
}

\section{Keywords}

Colorectal cancer - Colon cancer screening ·

Colonoscopy - Computed tomographic colonography · Magnetic resonance colonography

\section{Summary}

Background: Colorectal cancer (CRC) is one of the leading causes of cancer-related death in the Western world. The incidence could be reduced if this cancer were to be diagnosed at an early stage of disease. A competition has started between the existing screening methods to be the most efficient in detecting premalignant conditions. This review illustrates the current state of screening techniques for CRC. Method: Pubmed was searched for meta-analyses and prospective studies on screening for CRC, with an emphasis on colonography, computed tomographic colonography (CTC), magnetic resonance colonography (MRC), stool DNA testing, and colon capsule endoscopy, and critical appraisal of the research was done by the reviewers. Results: The imaging techniques (CTC and MRC) had similar detection rates for bigger lesions ( $\geq 10 \mathrm{~mm}$ ) as colonoscopy. High-definition colonoscopy showed better efficiency with smaller lesions. The techniques developing around colonoscopy such as the retro-viewing colonoscope, the balloon colonoscope, or the 330-degree viewing colonoscope try to enhance efficacy by reducing the adenoma miss rate in right-sided, non-polypoid lesions. Colon capsule endoscopy and the stool detection systems are limited to identifying cancer but not necessarily adenomas. Conclusion: Colonoscopy is the preferred CRC screening strategy and the undisputed gold standard in terms of efficacy.

\author{
Schlüsselwörter \\ Kolorektalkarzinom - Darmkrebsvorsorgeuntersuchung · \\ Koloskopie - Computertomographiekolonographie · \\ Magnetresonanzkolonographie
}

\section{Zusammenfassung:}

Hintergrund: Das Kolorektalkarzinom (KRK) ist in der westlichen Welt einer der führenden Gründe für das Versterben im Rahmen von Tumorerkrankungen. Nur eine frühe und effektive Vorsorge vermag zurzeit die Inzidenz zu reduzieren. Folglich findet heute ein regelrechter Wettbewerb zwischen den verschiedenen Vorsorgemöglichkeiten statt, und jede nimmt für sich die beste Effizienz in Anspruch. In der nachfolgenden Übersicht werden die verschiedenen Möglichkeiten der kolorektalen Krebsvorsorge kritisch unter Beachtung der aktuellen Studienlage beurteilt. Methode: Die aktuelle Recherche wurde mittels Pubmed durchgeführt. Dabei wurden Meta-AnaIysen und prospektive Studien über Darmkrebsvorsorgeuntersuchung gesucht, und ein besonderer Schwerpunkt wurde folgend auf die Koloskopie, die Computertomographiekolonographie (CTK), die Magnetresonanzkolonographie (MRK), die DNA-Stuhltests und die Kolonkapselendoskopie gesetzt. Ergebnisse: Die schnittbildgebenden Verfahren (CTK und MRK) zeigten zum Goldstandard Koloskopie vergleichbare Detektionsraten, vor allem für Läsionen $\geq 10 \mathrm{~mm}$. Die hochauflösende Koloskopie zeigte sich überlegen insbesondere bei kleineren, flachen Läsionen. Neue innovative Techniken wie das 'Retro-Viewing'-Koloskop, das neuartige Balloon-Koloskop oder das '330-Degree-Viewing'-Koloskop versuchen durch Reduktion der 'Miss'-Rate die Effizienz vor allem bei rechtsseitigen, flachen Polypen zu verbessern. Die DNA-Stuhltests und die Kolonkapselendoskopie zeigen verlässliche Aussagen nur bei Karzinomen. Schlussfolgerung: Die Koloskopie ist die bevorzugte Darmkrebsvorsorgeuntersuchung und ist bezüglich der Effizienz der unangefochtene Goldstandard.

\section{KARGER \\ Fax +497614520714 \\ Information@Karger.com}

www.karger.com
(C) 2014 S. Karger GmbH, Freiburg

1662-6664/14/0301-0018\$39.50/0

Accessible online at:

www.karger.com/vim
PD Dr. Arthur Hoffman

Medizinische Klinik

St. Marienkrankenhaus Frankfurt

Richard-Wagner-Straße 14, 60318 Frankfurt, Germany

a.hoffman@katharina-kasper.de 


\section{Introduction}

Colorectal cancer (CRC) is a commonly diagnosed cancer with a high incidence in the Western world. It is the second most common cancer $(447,000$ in the year 2012) and one of the leading causes of cancer-related death $(215,000$ in the year 2012 ) in Europe [1-3]. Because $75 \%$ of all new cases occur in an average-risk population, prevention and early detection have become an integral part of prevention programs which have been established in many countries, including Germany where every insured person from the age of 55 years can receive a screening colonoscopy for early detection of CRC [4-6].

Since conventional carcinomas arise from the so-called 'adenoma-carcinoma sequence' within approximately 10 years, the most important prognostic factor for the survival of a patient with CRC is the stage at which the disease is diagnosed [7-11]. Detection programs should be performed exactly in this time window, and it is estimated that $95 \%$ of all patients with CRC would benefit from a curative approach if diagnosed at an early stage [12]. Furthermore, the US National Polyp Study Workgroup estimated that $76-90 \%$ of cancers could even be prevented by regular early detection $[13,14]$.

Based on 88,902 participants followed over a period of 22 years, colonoscopy and sigmoidoscopy were associated with a reduced incidence of cancer of the distal colorectum, and colonoscopy was also associated with a modest reduction in the incidence of proximal colon cancer; however, only colonoscopy was associated with reduced mortality from proximal colon cancer [15]. An increase in the proportion of the population undergoing screening colonoscopy and the removal of precancerous polyps is thought to account for at least part of this decrease, especially given the fact that the frequency of missed right-sided proximal lesions increased substantially only after sigmoidoscopy $[15,16]$. However, more recent data has shown that parallel to the so-called conventional adenoma pathway exists a new serrated pathway to which the (sessile) serrated adenomas/polyps belong [17, 18]. Because of their characteristics of having a shallow and hard-to-detect growth pattern, being increasingly found in the right-sided colon, and having a greater potential of developing into CRC compared to traditional adenomas, these lesions are thought to be accountable for the so-called interval carcinomas [19, 20]. Based on this knowledge, screening modalities and screening intervals may have to be redefined.

\section{Competition in Screening: 'The Race Is on'}

\section{Conventional Screening Colonoscopy}

Today, it is evident that in individuals older than 50 years colonoscopy is an important screening option for detecting colorectal lesions. Highly ranked editorials have advocated colonoscopy as the preferred CRC screening strategy, which may have motivated physicians to switch from sigmoidoscopies to complete colonoscopy. In parallel, the percentage of physicians who believe that colonoscopy is very effective in reducing CRC mortality increased by $10-15 \%$ in the last 20 years [21-24]. Colonoscopy has maintained its place as the gold standard for screening and surveillance of CRC. The goal of every colonoscopy must be the detection of any premalignant condition of the colon (fig. 1). Advanced cancers and polypoid or protruded adenomas are easy to identify, and previous large-scale screening colonoscopy studies have assessed the use of colonoscopy for special-risk rather than average-risk populations. For example, in the study by Lieberman et al. [25], $13.9 \%$ of the screened population had a family history of CRC; in the study by Regula et al. [26], 13.3\% of the 50-66 age group and $66.3 \%$ of the $40-49$ age group had a family history of CRC. Schoenfeld et al. [27] screened only women; and other studies were not comprehensive as they limited their analysis to the 50-75 age range. Thus, concerns that the protective effect of colonoscopy is lower than previously believed have shifted attention to improving the precision of colonoscopy. Despite great advances and efforts having been made in recent years to optimize the quality of colonoscopy, updated guidelines have expanded the menu of recommended test options to include computed tomographic colonography (CTC), fecal DNA testing, magnetic resonance colonography (MRC), and capsule colonoscopy. Also, despite all its benefits, colonoscopy is still an invasive procedure which often requires sedation and full bowel preparation, and can in rare cases be associated with potentially life-threatening complications.

\section{Computed Tomographic Colonography}

Single or double contrast enema of the colon was the first radiologic technique to examine the lumen of the colon. Though this examination can identify stenosis or tumors, it has a low sensitivity for recognizing polyps. Furthermore, it demands advanced technology to achieve high-quality resolution with low exposure. CTC, also termed virtual colonoscopy, is an advanced radiological technique with significantly
Fig. 1. a-c. Polypectomy of a flat polyp in the right-sided colon (Paris classification Ib).

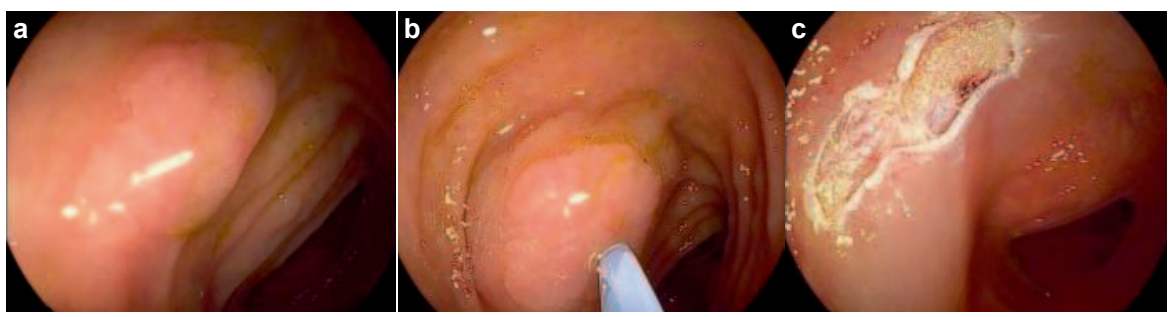


Fig. 2. Computed tomographic colonography (CTC) (property of Dr. Kukuk University Bonn, Germany).

Fig. 3. Adenoma detection with computed tomographic colonography (CTC) (property of Dr. Kukuk University Bonn, Germany).
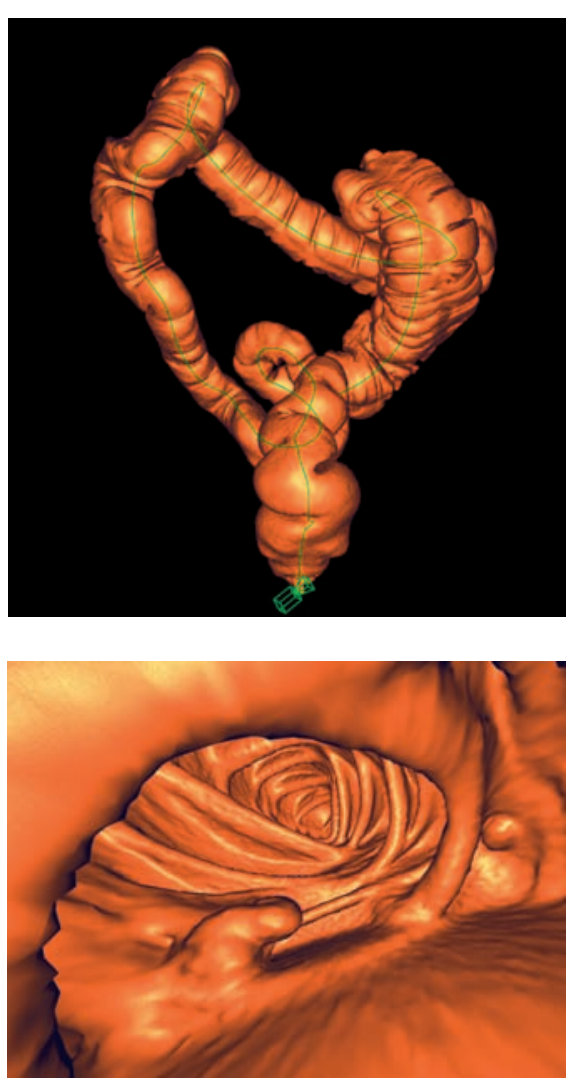

Fig. 4. Magnetic resonance colonography (MRC) (property of Dr. Kukuk University Bonn, Germany).

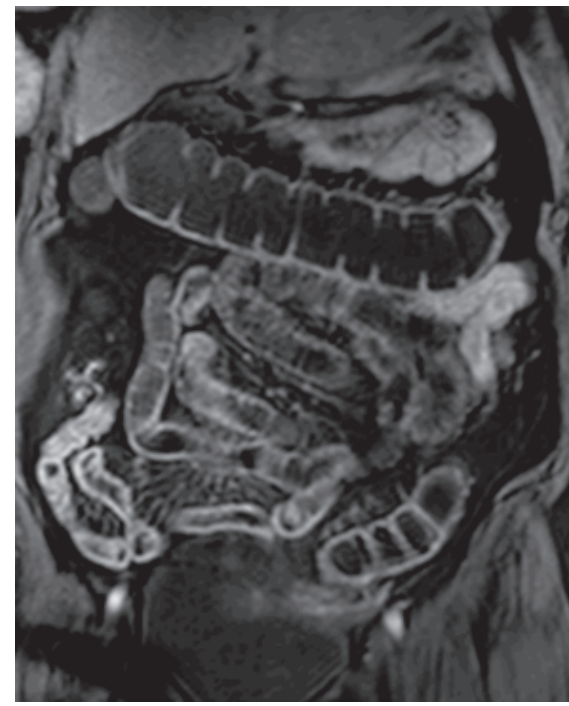

which findings should trigger an immediate colonoscopy. Often, repeat CTC is recommended for polyps measuring 6-9 mm. Here, substantial criticism can be raised, because flat and depressed neoplasia might be overlooked. On the other hand, the advantages of CTC are that almost the entire surface of the colon can be visualized. The use of last-generation CTC systems can minimize the radiation dose. Further advantages of CTC are that it is less burdensome and has a very low overall complication rate $(0.02 \%)$. The risk of serious adverse events is lower compared to colonoscopy which has a complication risk of $0.1-0.3 \%$ [40-43]. Whether the visualization of extracolonic structures and subsequent detection of potential pathologies is an advantage or disadvantage, is frequently debated and remains unclear since the majority of potentially important findings ultimately emerge as clinically unimportant in further tests and lead to patient anxiety and increment of health care costs for diagnostic follow-up [44, 45].

\section{Magnetic Resonance Colonography}

The radiation dose involved in CTC has led several investigators to evaluate the role of MRC. At a population level, if MRC were to be validated for screening purposes, the implications may be substantial. For MRC, the colon is filled with water combined with a paramagnetic contrast agent such as gadolinium, and the technique relies on ultra-fast, T1-weighted data acquisition collected during a single breath hold [46]. The lumen of the colon thus appears bright and the walls dark. Lesions within the wall protrude into the bright lumen, appearing as filling defects (fig. 4). The difficulty in differentiating masses from feces can be avoided by imaging the patient in prone and supine position, and more recently by using new techniques to render the lumen and feces dark while enhancing the colonic walls. This so-called fecal tagging (FT), or dark-lumen colonography, is facilitated by the oral administration of barium sulphate which renders the lumen and feces dark [47, 48]. The technique can be performed without bowel preparation, were $<10 \mathrm{~mm}$. Furthermore, there is an ongoing debate about 
which may even increase patient acceptance, particularly for elderly patients who are not able to tolerate full bowel preparation. However, diagnostic MRC relies heavily on good bowel distension and sufficient contrast between the bowel lumen and the colonic wall to highlight lesions, and these methodological aspects have an immediate impact on the imaging results. A number of prospective, comparative studies of MRC versus conventional colonoscopy have been reported, assessing the accuracy of MRC as a possible diagnostic tool for CRC and polyps $[49,50]$. Despite the heterogeneity of the studies, the overall diagnostic accuracy of MRC was only adequate compared to colonoscopy, with a pooled sensitivity of $75 \%$ and a specificity of $96 \%$. MRC was more useful in the detection of bigger malignant lesions, with a sensitivity of $91 \%$ and a specificity of $98 \%$ [49-55]. The potential advantages of MRC over conventional colonoscopy are that it is less invasive with less potential serious complications, requires less time for the investigation, and has been reported to have good patient acceptability. Extracolonic pathologies related to CRC such as lymph node or distant metastasis can also be evaluated during the investigation, and the MRC can hence be used for the staging process. In the future, specialized software may even enable the viewer to digitally straighten the colon in areas where folds may mask potential pathologies. However, there are also potential disadvantages of MRC, including lack of universal availability, unsuitability for biopsies, susceptibility to motion artifacts, and need for breath holding. Cost is also an important issue; one study reported MRC examination costs of approximately USD 550, and cost-effectiveness has not yet been formally investigated in clinical studies [48]. However, most of all MRC must be evaluated in terms of its potential to recognize flat and depressed neoplasias, which is challenging and only possible by meticulous inspection and classification of discrete mucosal alterations.

\section{Colon Capsule Endoscopy}

Various media campaigns and other initiatives to promote screening colonoscopy have had surprisingly little impact [56]. The reasons for the limited acceptance of CRC screening, especially of colonoscopy, are diverse. Apart from general doubts and fears, a contributing factor may be the perception of colonoscopy as being painful and unpleasant. Capsule endoscopy was introduced some years ago primarily for small bowel diagnostics, but has been extended to the colon with a modified capsule used for capsule colonoscopy [57, 58]. The PillCam ${ }^{\circledR}$ colon capsule (Given Imaging Ltd., Yoqneam, Israel) provides a screening solution which is minimally invasive, safe, and does not require sedation. It is well accepted by patients although still requiring thorough bowel cleaning, and is mainly recommended to people who have up to this point rejected CRC screening programs [58]. It is an easy-to-perform examination with an excellent negative predictive value for application in screening procedures under routine conditions. However, diagnostic accuracy for relevant-sized polyps (i.e. sensitivity) is low. First studies have shown $65-75 \%$ accuracy for adenoma detection in the large bowel when compared with colonoscopy [59-63]. However, with capsule colonoscopy, there is a fourfold increase in endoscopic screening, with men in particular finding capsule colonoscopy more acceptable. Colon capsule screening is expensive because there are no screening programs supporting it as the primary choice. Thus, the colon capsule has to be paid for by the patient, which in turn hinders broad acceptance.

\section{Stool DNA Testing}

Since 2002, the guaiac-based fecal occult blood test (gFOBT) is part of the early CRC detection program in Germany. Although the sensitivity for detecting CRC is low (13-50\%) and even lower for advanced neoplasia (11-27\%), several randomized controlled trials have shown that biennial gFOBT screening leads to a CRC mortality reduction of approximately $14 \%$ after 10 years of screening [64-69]. Understandably, there has been minimal impact on CRC incidence [70]. Immunological stool testing provides better sensitivities and accuracy rates, and several gastroenterology societies are now recommending this test (iFOBT) rather than gFOBT [71-73].

A new test is the so-called stool DNA test (sDNA) which offers a biologically rational approach based on tumor cell exfoliation [71]. However, along with the problems of stool collection and delivery, this examination is limited to identifying cancer and not necessarily adenomas. The study of the firstgeneration sDNA test by Imperiale et al. [70] using a DNA marker panel comprising 21 mutations showed a sensitivity of $52 \%$ for invasive cancers compared to $13 \%$ for FOBT and a sensitivity of $18 \%$ for advanced neoplasia. First preliminary studies have shown that by using a large pool of genetic markers the sensitivity for large adenomas was $82 \%$ and for CRC $91 \%$, with an overall specificity of $93 \%$ [72]. A recently published, blinded, multicenter, case-control study using archived stool samples of 678 patients and a next-generation sDNA test by Ahlquist et al. [73] reported a sensitivity of $85 \%$ for patients with CRC and $54 \%$ for patients with adenomas $>1 \mathrm{~cm}$, with $90 \%$ specificity. Although the manufacturer recommends a 5-year screening interval, no formal evaluation of timing has been performed in clinical studies. Acceptance with caution with regard to sDNA testing has been declared by the American Cancer Society; however, the biggest limitation remains the low sensitivity for advanced adenomas, as the primary goal in cancer screening is prevention rather detection of cancer.

\section{Interval Cancers and Adenoma Detection Miss Rate}

A pooled adenoma detection miss rate of $22 \%$ (range 15 $32 \%$ ) in tandem colonoscopy studies and a recent large casecontrol study by Baxter et al. [74] have raised another question regarding the yield of screening colonoscopy in reducing mortality due to interval cancers, as screening colonoscopy was associated with significantly reduced mortality from leftsided lesions (odds ratio (OR) 0.33) but showed only minor 
Table 1. High-definition colonoscopy and adenoma detection rate
Fig. 5. High-definition colonoscopy.

\begin{tabular}{lllllllr}
\hline Author, year [ref.] & $\begin{array}{l}\text { Study design/ } \\
\text { objective }\end{array}$ & $\begin{array}{l}\text { Wide } \\
\text { angle }\end{array}$ & $\begin{array}{l}\text { Patients, } \\
\mathrm{n}\end{array}$ & $\begin{array}{l}\text { Adenoma } \\
\text { detection } \\
\text { rate, } \%\end{array}$ & $\mathrm{p}$ & $\begin{array}{l}\text { Absolute } \\
\text { increase, } \\
\%\end{array}$ & $\begin{array}{l}\text { Relative } \\
\text { increase, } \\
\%\end{array}$ \\
\hline East et al., 2008 & cohort & no & 130 & 65 & 0.20 & 11 & 18 \\
Pellise et al., 2008 & randomized & yes & 620 & 26 & 0.85 & 1 & 4 \\
Burke et al., 2010 & cohort & yes & 852 & 23 & 0.36 & - & 13 \\
Tribonias et al., 2009 & randomized & yes & 390 & 54 & 0.16 & 8 & 16 \\
Buchner et al., 2010 & cohort & yes & 2,430 & 27 & 0.01 & 4.2 & 17 \\
Hoffman et al., 2012 & randomized & no & 220 & 38 & 0.001 & 25 & 192 \\
\hline
\end{tabular}

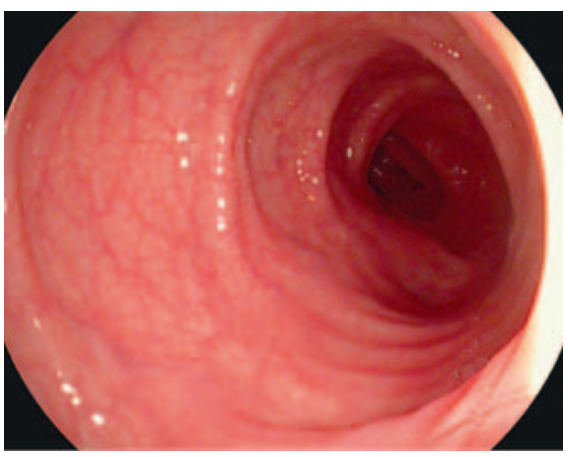

allows detection of more adenomas in a higher proportion of patients than SD colonoscopy; the difference is mostly due to a better detection of polyps that are small $(\leq 5 \mathrm{~mm})$ and flat.

\section{Technologies on the Horizon}

An apparently leading cause of missed polyps during colonoscopy are polyps that are located behind haustral folds in the colon, and are therefore hidden from conventional, forwardviewing endoscope optics. It was demonstrated that occasional straightening of haustral folds during colonoscopy by a plastic cap mounted on the endoscope tip increases the polyp detection yield [78]. A study in 6,185 patients by Westwood et al. [78] reported a miss rate of $12.2 \%$ in the cap-assisted colonoscopy group versus a $28.6 \%$ miss rate in the standard colonoscopy group, implying a positive effect of cap employment on the polyp detection rate. In contrast, another study performed by Tee et al. [79] in 400 subjects reported that there was no significant polyp detection rate difference between standard colonoscopy and cap-assisted colonoscopy (31.3 vs. 32.8\%).

Recently, a retrograde viewing device (Third Eye Retroscope; Avantis Medical, Sunnyvale, CA, USA) was introduced for use during colonoscopy with standard endoscopes, and was analyzed in a single randomized controlled trial (same-day tandem examinations) [80]. This technique is aimed at allowing inspection of the proximal surface of haustral folds not in the line of sight of the endoscope's forward-viewing optics, thereby allowing detection of polyps that are located behind such folds. Intention-to-treat and per-protocol analyses included 395 and 349 patients, respectively. Use of the retrograde viewing device was associated with a $23 \%$ increase in the total number of adenomas detected compared with standard colonoscopy (after correcting for the second-pass effect), and the relative risk of missing lesions with standard colonoscopy compared with colonoscopy using the retrograde viewing device was 2.56 for polyps ( $p<0.001)$ and 1.92 for adenomas $(p=0.029)$. Previous uncontrolled studies also suggested that the retrograde viewing device may allow detection of $10 \%$ more adenomas compared to standard colonoscopy [81]. However, in the intention-to-treat analysis, the benefit in the total number of adenomas detected dropped from 23 to $14 \%$, and the relative risk of missing lesions with standard colonoscopy compared with colonoscopy using nomas, could be identified [77]. In summary, HD colonoscopy 


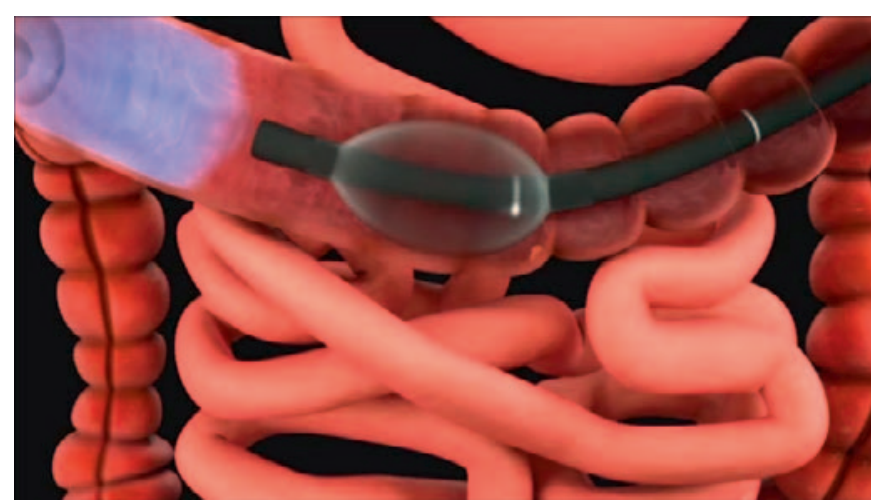

Fig. 6. G-Eye balloon colonoscopy with inflated balloon at the distal tip of the colonoscope. The balloon is inflated to straighten intestinal folds in the colon (NaviAid ${ }^{\mathrm{TM}}$ G-EYE; property of Smart Medical Systems, Ra'anana, Israel).

the retrograde viewing device became not significant for adenomas. Furthermore, the cost of this technique is still relatively high and needs the approval of more prospective studies.

The new G-Eye system (NaviAid ${ }^{\mathrm{TM}}$ G-EYE; Smart Medical Systems, Ra'anana, Israel) is a balloon colonoscope comprising a standard colonoscope with a reprocessable, permanently integrated balloon at its distal tip. The balloon pressure is controlled through a unique inflation system providing predetermined, user-selectable, anchoring and intermediate (low) pressure levels (fig. 6). First results from a prospective multicenter back-to-back study including 126 patients were as follows: The G-Eye balloon colonoscopy detected 23 additional polyps, which means a promising $115 \%$ additional adenoma detection rate. The balloon colonoscope's additional detection rate ratio, calculated as the ratio between balloon colonoscopy second-pass additional detection and balloon colonoscopy first-pass miss rate, was 25.5 (115/4.51) [82]. The results from this first multicenter study are very promising, and further studies are ongoing.

Another potential reason for high adenoma miss rates is inadequate visualization of the proximal aspect of colonic folds and flexures. Full spectrum endoscopy (Fuse ${ }^{\mathrm{TM}}$; EndoChoice, Alpharetta, GA, USA) utilizes unique imaging technology which allows the endoscopist to view 330 degrees while maintaining identical standard colonoscope technical features (fig. 7). The results for this new technique were a $32.9 \%$ increased polyp detection rate (per patient analysis) and a 39/49 (79.6\%) increased polyp detection rate (per polyp analysis). Furthermore, on subsequent Fuse colonoscopy, there were an additional 15/88 (17.1\%) subjects who had at least 1 adenoma detected, yielding an additional 21 adenomas. This is an increment of $17.1 \%$ in the adenoma detection rate (per patient analysis) and a 21/28 (75.0\%) increased adenoma detection rate (per adenoma analysis) using Fuse colonoscopy [83]. However, as with all new technology, there often is initial enthusiasm, but advantages have to be proved in a more clinical setting and with practice.
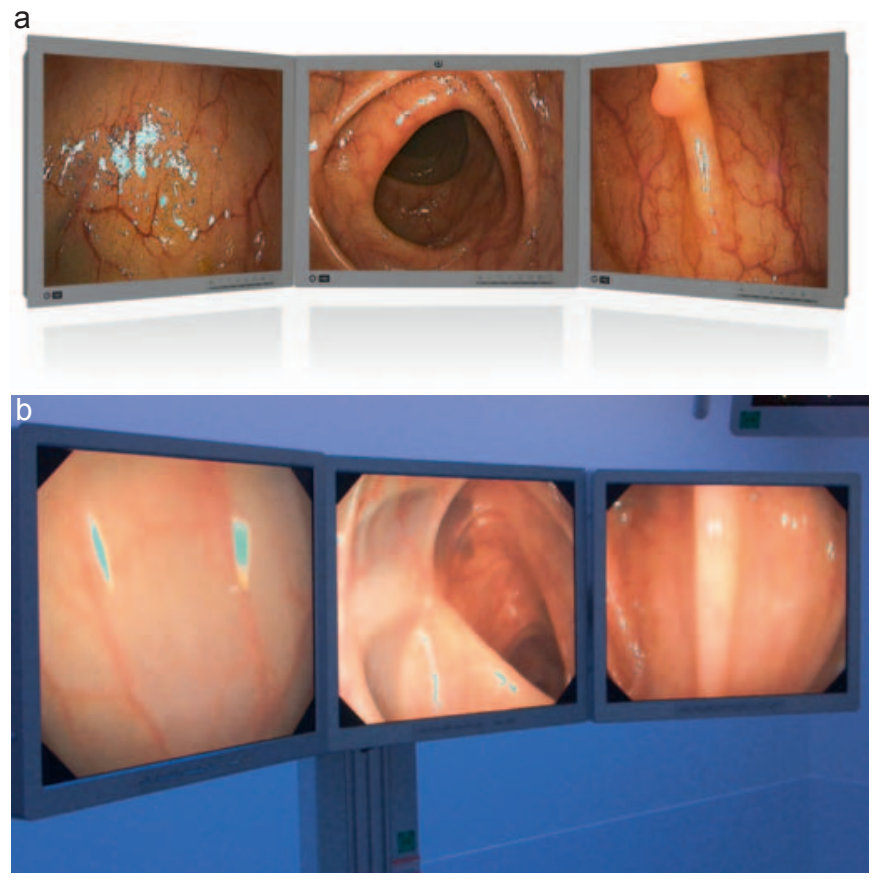

Fig. 7. a, b. Fuse colonoscopy utilizes unique imaging technology which allows the endoscopist to view 330 degrees while maintaining identical standard colonoscope technical features (property of Fuse ${ }^{\mathrm{TM}}$; EndoChoice, Alpharetta, GA, USA).

\section{Conclusion}

The optimal screening strategy for CRC in an average-risk population is dependent on the efficacy and safety of the tests, cost-effectiveness, and likelihood of patient compliance. Colonoscopy is the undisputed gold standard in terms of efficacy, having the highest sensitivity and specificity and offering the capacity to carry out therapeutic intervention during the procedure (e.g. polypectomy). Furthermore, clinical evidence amassed over several decades indicates that routine colonoscopy screening detects $\mathrm{CRC}$ at an earlier stage, reduces the incidence of $\mathrm{CRC}$ or the progression of early CRC through polypectomy, and significantly reduces cancer-related mortality. However, colonoscopy is the most invasive of the currently available screening modalities. In the ambulatory setting, the procedurerelated morbidity rate of colonoscopy is $0.1-0.3 \%$, with a $0.03 \%$ perforation rate and no mortality $[74,75]$. Screening the entire population aged $\geq 50$ years is an expensive proposition; however, the costs of missing a curable malignancy or failing to prevent cancer by not resecting a premalignant lesion (polyp) may be significantly greater. The potential advantages of CTC and $\mathrm{MRC}$, including rapid image acquisition and processing, noninvasiveness, and decreased procedural risks of perforation, bleeding, and sedation complications, may serve to improve the low rates of CRC screening that are currently observed in our society. A lot of studies add to the body of literature regarding the efficacy of screening programs based on computed tomogra- 
phy and magnetic resonance imaging, which are likely to become acceptable CRC screening tests on a par with colonoscopy. Issues remain, however, regarding the extension and reproducibility of these results in the true community setting. There are concerns regarding thresholds for referrals, appropriate intervals between studies, the optimal management of extracolonic findings, and radiation exposure with CTC that remain unanswered so far. Stool-based tests are categorized as tests which can primarily detect cancer early on according to the joint guideline from the American Cancer Society, the Multi-Society Task Force on Colorectal Cancer, and the American College of Radiology. Hence, considering that the primary goal is cancer prevention rather than cancer detection, they are not very suit- able. Although colonoscopy remains the major gastrointestinal endoscopy procedure, it is well known that lesions are missed during routine colonoscopy and interval cancers still remain an unsolved problem. A lot of new medical devices are coming to the market to reduce the adenoma miss rate, and first studies show promising results; however, all these techniques have to be tested in further prospective studies.

\section{Disclosure Statement}

A. Hoffman, D. Teubner, and R. Kiesslich declare that no conflict of interest exists.

\section{References}

1 Gupta AK, Brenner DE, Turgeon DK: Early detection of colon cancer: new test on the horizon. Mol Diagn Ther 2008;12:77-85.

$\checkmark 2$ Ferlay J, Steliarova-Foucher E, Lortet-Tieulent J, et al: Cancer incidence and mortality patterns in Europe: estimates for 40 countries in 2012. Eur J Cancer 2013;49:1374-1403.

3 Richtlinie des Gemeinsamen Bundesausschusses über die Früherkennung von Krebserkrankungen (Krebsfrüherkennungs-Richtlinie). Last update 16/12/2010. Bundesanzeiger 2011.

4 Jemal A, Tiwari RC, Murray T, et al: Cancer statistics, 2004. CA Cancer J Clin 2004;54:8-29.

5 Levin B, Lieberman D, McFarland B, Andrews KS, Brooks D, Bond J, Dash C, Giardiello FM, Glick S, Johnson D, Johnson CD, Levin TR, Pickhardt PJ, Rex DK, Smith RA, Thorson A, Winawer SJ; American Cancer Society Colorecta Cancer Advisory Group; US Multi-Society Task Force; American College of Radiology Colon Cancer Committee: Screening and surveillance for the early detection of CRC and adenomatous polyps, 2008: a joint guideline from the American Cancer Society, the US Multi-Society Task Force on Colorectal Cancer, and the American College of Radiology. Gastroenterology 2008;134:1570-1595.

6 Boyle P, Ferlay J: Cancer incidence and mortality in Europe, 2004. Ann Oncol 2005;16:481-488.

7 Winawer SE, Zauber AG, Stewart E, O'Brien MJ: The natural history of colorectal cancer. Opportunities for intervention. Cancer 1991;67:1143-1149.

$>8$ O'Brien MJ, Winawer SJ, Zauber AG, et al: The National Polyps Study. Patient and polyp characteristics associated with high-grade dysplasia in colorectal adenomas. Gastroenterology 1990;98: 371-379.

9 Bond JH: Colon polyps and cancer. Endoscopy 2003;35:27-35.

10 Winawer SJ, Fletcher RH, Miller L, et al: Colorectal cancer screening: clinical guidelines and rationale. Gastroenterology 1997;112:594-642.

11 Winawer SJ: Natural history of colorectal cancer. Am J Med 1999;106:3S-6S.

$\checkmark 12$ Leslie A, Carey FA, Pratt NR, Steele RJ: The colorectal adenoma-carcinoma sequence. Br J Surg 2002;89:845-860.

13 Winawer SJ, Zauber AG, Ho MN, et al: The National Polyp Study Workgroup. Prevention of colorectal cancer by colonoscopic polypectomy. N Engl J Med 1993;329:1977-1983.
14 Howlader N, Noone AM, Krapcho M, Neyman N, Aminou R, Altekruse SF, Kosary CL, Ruhl J, Tatalovich Z, Cho H, Mariotto A, Eisner MP, Lewis DR, Chen HS, Feuer EJ, Cronin KA (eds): SEER Cancer Statistics Review, 1975-2010. National Cancer Institute, Bethesda, MD. seer.cancer.gov/csr/1975_2010/.

15 Nishihara R, Wu K, Lochhead P, et al: Long-term colorectal-cancer incidence and mortality after lower endoscopy. N Engl J Med 2013;369:1095-1105.

16 Lakoff J, Paszat LF, Saskin R, et al: Risk of developing proximal vs. distal colorectal cancer after a negative colonoscopy: a population-based study. Clin Gastroenterol Hepatol 2008;6:1117-1121.

17 Baretton GB, Autschbach F, Baldus S, et al: Histopathological diagnosis and differential diagnosis of colorectal serrated polys: findings of a consensus conference of the working group 'gastroenterological pathology of the German Society of Pathology' (article in German). Pathologe 2011;32:76-82.

18 Bosman FT Carneiro F, Hruban RH, Theisen ND (eds): WHO Classification of Tumors of the Digestive System, ed 4. Lyon, IARC Press, 2010.

19 Torlakovic E, Skovlund E, Snover DC, Torlakovic G, Nesland JM: Morphologic reappraisal of serrated colorectal polyps. Am J Surg Pathol 2003;27:65-81.

20 Huang CS, Farraye FA, Yang S, O'Brien MJ: The clinical significance of serrated polyps. Am J Gastroenterol 2011;106:229-240; quiz 41

21 Lansdorp-Vogelaar I, Knudsen AB, Brenner H: Cost-effectiveness of colorectal cancer screening. Epidemiol Rev 2011;33:88-100.

21 U.S. Preventive Services Task Force: Screening for colorectal cancer: recommendation and rationale. Ann Intern Med 2002;137:129-131.

22 National Committee for Quality Assurance (NCQA), Washington DC: HEDIS and Quality Measurement (HEDIS Archives, HEDIS 2004). www.ncqa.org/HomePage.aspx.

23 Pignone M, Rich M, Teutsch SM, Berg AO, Lohr $\mathrm{KN}$ : Screening for colorectal cancer in adults at average risk: a summary of the evidence for the U.S. Preventive Services Task Force. Ann Intern Med 2002;137:132-141.

24 Meissner HI, Breen N, Klabunde CN, Vernon SW: Patterns of colorectal cancer screening uptake among men and women in the United States. Cancer Epidemiol Biomarkers Prev 2006;15:389-394.

25 Lieberman DA, Weiss DG, Bond JH, et al: Use of colonoscopy to screen asymptomatic adults for colorectal cancer. Veterans Affairs Cooperative Study Group 380. N Engl J Med 2000;343:162-168.
6 Regula J, Rupinski M, Kraszewska E, et al: Colonoscopy in colorectal-cancer screening for detection of advanced neoplasia. N Engl J Med 2006;355: 1863-1872.

27 Schoenfeld P, Cash B, Flood A, et al: Colonoscopic screening of average risk women for colorectal neoplasia. N Engl J Med 2005;352:2061-2068.

28 Halligan S, Wooldrage K, Dadswell E, et al: Computed tomographic colonography versus barium enema for diagnosis of colorectal cancer or large polyps in symptomatic patients (SIGGAR): a multicentre randomised trial. Lancet 2013;381:1185-1193.

29 Yee J, Weinstein S, Morgan T, Alore P, Aslam R: Advances in CT colonography for colorectal cancer screening and diagnosis. J Cancer 2013;4:200-209.

30 Hara AK, Blevins M, Chen MH, et al: ACRIN CT colonography trial: does reader's preference for primary two-dimensional versus primary threedimensional interpretation affect performance? Radiology 2011;259:435-441.

31 Atkin W, Dadswell E, Wooldrage K, et al: Computed tomographic colonography versus colonoscopy for investigation of patients with symptoms suggestive of colorectal cancer (SIGGAR): a multicentre randomised trial. Lancet 2013;381:1194-1202.

32 Pickhardt PJ, Hassan C, Halligan S, Marmo R: Colorectal cancer: CT colonography and colonoscopy for detection - systematic review and metaanalysis. Radiology 2011;259:393-405.

33 De Haan MC, van Gelder RE, Graser A, Bipat S, Stoker J: Diagnostic value of CT-colonography as compared to colonoscopy in an asymptomatic screening population: a meta-analysis. Eur Radiol 2011;21:1747-1763.

34 Johnson CD, Chen MH, Toledano AY, et al: Accuracy of CT colonography for detection of large adenomas and cancers. N Engl J Med 2008;359: 1207-1217.

35 Rex DK, Overhiser AJ, Chen SC, Cummings OW, Ulbright TM: Estimation of impact of American College of Radiology recommendations on CT colonography reporting for resection of high-risk adenoma findings. Am J Gastroenterol 2009;104: 149-153.

36 Lieberman D, Moravec M, Holub J, Michaels L, Eisen G: Polyp size and advanced histology in patients undergoing colonoscopy screening: implications for CT colonography. Gastroenterology 2008; 135:1100-1105. 
-37 Yee J, Kumar NN, Godara S, et al: Extracolonic abnormalities discovered incidentally at CT colonography in a male population. Radiology 2005;236: 519-526.

38 Sutherland T, Coyle E, Lui B, Lee WK: Extracolonic findings at CT colonography: a review of 258 consecutive cases. J Med Imaging Radiat Oncol 2011;55:149-152.

39 Pickhardt PJ, Lam VP, Weiss JM, Kennedy GD, Kim DH: Carpet lesions detected at CT colonography: clinical, imaging, and pathologic features. Radiology 2013;Epub ahead of print.

40 Ristvedt SL, McFarland EG, Weinstock LB, Thyssen EP: Patient preferences for CT colonography, conventional colonoscopy, and bowel preparation. Am J Gastroenterol 2003;98:578-585

41 Jensch S, Bipat S, Peringa J, et al: CT colonography with limited bowel preparation: prospective assessment of patient experience and preference in comparison to optical colonoscopy with cathartic bowel preparation. Eur Radiol 2010;20:146-156.

42 Kim DH, Pickhardt PJ, Taylor AJ, et al: CT colonography versus colonoscopy for the detection of advanced neoplasia. N Engl J Med 2007;357:1403-1412.

43 Panteris V, Haringsma J, Kuipers EJ: Colonoscopy perforation rate, mechanisms and outcome: from diagnostic to therapeutic colonoscopy. Endoscopy 2009;41:941-951.

-44 Yee J, Kumar NN, Godara S, et al: Extracolonic abnormalities discovered incidentally at CT colonography in a male population. Radiology 2005;236: 519-526.

45 Gluecker TM, Johnson CD, Wilson LA, et al: Extracolonic findings at CT colonography: evaluation of prevalence and cost in a screening population. Gastroenterology 2003;124:911-916.

46 Luboldt W, Bauerfeind P, Steiner P, Fried M, Krestin GP, Debatin JF: Preliminary assessment of three-dimensional magnetic resonance imaging for various colonic disorders. Lancet 1997;349:12881291.

47 Lauenstein TC, Herborn CU, Vogt FM, Gohde SC, Debatin JF, Ruehm SG: Dark lumen MR-colonography: initial experience. Rofo 2001;173:785-789.

48 Lauenstein TC, Goehde SC, Ruehm SG, Holtmann G, Debatin JF: MR colonography with bariumbased fecal tagging: initial clinical experience. Radiology 2002;223:248-254.

49 Kuehle CA, Langhorst J, Ladd SC, et al: Magnetic resonance colonography without bowel cleansing: a prospective cross sectional study in a screening population. Gut 2007;56:1079-1085.

50 Graser A, Melzer A, Lindner E, et al: Magnetic resonance colonography for the detection of colorectal neoplasia in asymptomatic adults. Gastroenterology 2013;144:743-750.e2.

51 Luboldt W, Bauerfeind P, Wildermuth S, Marincek B, Fried M, Debatin JF: Colonic masses: detection with MR colonography. Radiology 2000;216:383-388.

52 Ajaj W, Pelster G, Treichel U, et al: Dark lumen magnetic resonance colonography: comparison with conventional colonoscopy for the detection of colorectal pathology. Gut 2003;52:1738-1743

53 Ajaj W, Lauenstein TC, Pelster G, Goehde SC, Debatin JF, Ruehm SG: MR colonography: how does air compare to water for colonic distention? J Magn Reson Imaging 2004;19:216-221.

54 Pappalardo G, Polettini E, Frattaroli FM, et al: Magnetic resonance colonography versus conventiona colonoscopy for the detection of colonic endoluminal lesions. Gastroenterology 2000;119:300-304.
55 Leung WK, Lam WW, Wu JC, et al: Magnetic resonance colonography in the detection of colonic neoplasm in high-risk and average-risk individuals. Am J Gastroenterol 2004;99:102-108.

56 Maar C: Increasing public acceptance for CRC screening through public relation campaigns and networking. Z Gastroenterol 2008;46(suppl 1):S35-S37.

57 Ziegler M, Schubring-Giese B, Bühner M, Kolligs FT: Attitude to secondary prevention and concerns about colonoscopy are independent predictors of acceptance of screening colonoscopy. Digestion 2010;81:120-126.

58 Wahls TL, Peleg I: Patient- and system-related barriers for the earlier diagnosis of colorectal cancer. BMC Fam Pract 2009;10:65.

59 Eliakim R, Fireman Z, Gralnek IM, Yassin K, Waterman M, Kopelman Y, Lachter J, Koslowsky B, Adler SN: Evaluation of the PillCam Colon capsule in the detection of colonic pathology: results of the first multicenter, prospective, comparative study. Endoscopy 2006;38:963-970.

60 Schoofs N, Devière J, Van Gossum A: PillCam colon capsule endoscopy compared with colonoscopy for colorectal tumor diagnosis: a prospective pilot study. Endoscopy 2006;38:971-977.

61 Van Gossum A, Munoz-Navas M, FernandezUrien I, Carretero C, Gay G, Delvaux M, Lapalus MG, Ponchon T, Neuhaus H, Philipper M, Costamagna G, Riccioni ME, Spada C, Petruzziello L, Fraser C, Postgate A, Fitzpatrick A, Hagenmuller F, Keuchel M, Schoofs N, Devière J: Capsule endoscopy versus colonoscopy for the detection of polyps and cancer. N Engl J Med 2009:361:1220.

62 Eliakim R, Yassin K, Niv Y, Metzger Y, Lachter J, Gal E, Sapoznikov B, Konikoff F, Leichtmann G, Fireman Z, Kopelman Y, Adler SN: Prospective multicenter performance evaluation of the secondgeneration colon capsule compared with colonoscopy. Endoscopy 2009;41:1026-1031.

63 Van Roon AH, Hol L, Wilschut JA, Reijerink JC, van Vuuren AJ, van Ballegooijen M, Habbema JD, van Leerdam ME, Kuipers EJ: Advance notification letters increase adherence in colorectal cancer screening: a population-based randomized trial. Prev Med 2011;52:448-451.

64 Heresbach D, Manfredi S, D'Halluin PN, Bretagne $\mathrm{JF}$, Branger B: Review in depth and meta-analysis of controlled trials on colorectal cancer screening by faecal occult blood test. Eur J Gastroenterol Hepatol 2006;18:427-433.

65 Mandel JS, Church TR, Ederer F, Bond JH: Colorectal cancer mortality: effectiveness of biennial screening for fecal occult blood. J Natl Cancer Inst 1999;91:434-437.

66 Scholefield JH, Moss S, Sufi F, Mangham CM, Hardcastle JD: Effect of faecal occult blood screening on mortality from colorectal cancer: results from a randomised controlled trial. Gut 2002;50:840-844.

67 Faivre J, Dancourt V, Lejeune C, et al: Reduction in colorectal cancer mortality by fecal occult blood screening in a French controlled study. Gastroenterology 2004;126:1674-1680.

68 Kronborg O, Jorgensen OD, Fenger C, Rasmussen $\mathrm{M}$ : Randomized study of biennial screening with a faecal occult blood test: results after nine screening rounds. Scand J Gastroenterol 2004;39:846-851.

69 Morikawa T, Kato J, Yamaji Y, Wada R, Mitsushima T, Shiratori Y: A comparison of the immunochemical fecal occult blood test and total colonoscopy in the asymptomatic population. Gastroenterology 2005;129:422-428.
70 Imperiale TF, Ransohoff DF, Itzkowitz SH, Turnbull BA, Ross ME: Fecal DNA versus fecal occult blood for colorectal-cancer screening in an averagerisk population. N Engl J Med 2004;351:2704-2714.

71 Ahlquist DA: Molecular detection of colorectal neoplasia. Gastroenterology 2010;138:2127-2139.

72 Ahlquist DA, Skoletsky JE, Boynton KA, et al Colorectal cancer screening by detection of altered human DNA in stool: feasibility of a multitarget assay panel. Gastroenterology 2000;119:1219-1227.

73 Ahlquist DA, Zou H, Domanico M, et al: Nextgeneration stool DNA test accurately detects colorectal cancer and large adenomas. Gastroenterology 2012;142:248-256; quiz e25-26.

74 Baxter N, Goldwasser M, Paszat L, et al: Association of colonoscopy and death from colorectal cancer. Ann Intern Med 2009;150:1-8.

75 Subramanian V, Mannath J, Hawkey CJ, Ragunath $\mathrm{K}$ : High definition colonoscopy vs. standard video endoscopy for the detection of colonic polyps: a meta-analysis. Endoscopy 2011;43:499-505.

76 Rastogi A, Early DS, Gupta N, et al: Randomized, controlled trial of standard-definition white-light, high-definition white-light, and narrow-band imaging colonoscopy for the detection of colon polyps and prediction of polyp histology. Gastrointest Endosc 2011;74:593-602.

77 Hoffman A, Sar F, Goetz M, et al: High definition colonoscopy combined with i-Scan is superior in the detection of colorectal neoplasias compared with standard video colonoscopy: a prospective randomized controlled trial. Endoscopy 2010;42:827-833.

78 Westwood DA, Alexakis N, Connor SJ: Transparent cap-assisted colonoscopy versus standard adult colonoscopy: a systemic review and meta-analysis. Dis Colon Rectum 2012;55:218-225.

79 Tee HP, Corte C, Al-Ghamdi H, Prakoso E, Darke J, Chettiar R, Rahman W, Davison S, Griffin SP, Selby WS, Kaffes AJ: Prospective randomized controlled trail evaluating cap-assisted colonoscopy vs standard colonoscopy, World J Gastroenterology 2010;16:3905-3910.

80 Triadafilopoulos G, Li J: A pilot study to assess the safety and efficacy of the Third Eye retrograde auxiliary imaging system during colonoscopy. Endoscopy 2008;40:478-482.

81 DeMarco DC, Odstrcil E, Lara LF, Bass D, Herdman C, Kinney T, Gupta K, Wolf L, Dewar T, Deas TM, Mehta MK, Anwer MB, Pellish R, Hamilton JK, Polter D, Reddy KG, Hanan I: Impact of experience with a retrograde-viewing device on adenoma detection rates and withdrawal times during colonoscopy: the Third Eye Retroscope study group. Gastrointest Endosc 2010;71:542-550.

82 Shpak B, Halpern Z, Kiesslich R, Moshkowitz M, Santo E, Hoffman A: Novel balloon-colonoscope for increased polyp detection rate - intermediate results of a randomized tandem study presented during EUGW 2013 (presentation number OP286), and also during ACG 2013.

83 Gralnek IM, Segol O, Suissa A, Siersema PD, Carr-Locke DL, Halpern Z, Santo E, Domanov S: A prospective cohort study evaluating a novel colonoscopy platform featuring full-spectrum endoscopy. Endoscopy 2013;44:697-702. 